\title{
The Effect of Massage to Blood Pressure and Decrease the Percentage of Body Fat at Dharmawanita Members of Sport Science Faculty UNP
}

\author{
Darni $^{1 *}$, Rosmaneli $^{2}$, and Wilda Welis ${ }^{3}$ \\ ${ }^{1,2,3}$ Faculty of Sports Sciences, Universitas Negeri Padang Padang, Indonesia \\ *Corresponding author. Email: darnidarni60@gmail.com
}

\begin{abstract}
This study aims to reveal the effect of massase on decreasing levels of fat, cholesterol, glucose, and blood pressure of Dharmawanita of FIK UNP women. The long-term goal of this research is to find a way or method to reduce levels of fat, cholesterol, glucose, and blood pressure. This research uses quantitative methods with pre-experimental designs with one group pretest - post test design. The subjects of the study were Dharmawanita from Sport Science Faculty (FIK) UNP. The variables to be studied are Massase, Fat Levels, Cholesterol, Glucose, and Blood Pressure. The research stage begins with the preparatory stage including the administration of research administration and the design of research instruments, the implementation stage includes the taking of body weight, height, glucose measurements, fat thickness and blood pressure measurements and the final stage includes data processing, data analysis and report writing. The results of the research that has been carried out obtained data that there was a decrease in levels of fat, cholesterol, glucose, and blood pressure of the member of Dharmawanita FIK UNP, where the average initial fat test level was 44, changed to 42. The results also showed that the average cholesterol in the initial sample test 247.3, it dropped to 191. The average initial test sample Glucose 124.6, dropped to 96.3. And the average initial test blood pressure sample of $122 / 70 \mathrm{mmHg}$ drops to $118 / 68 \mathrm{mmHg}$.
\end{abstract}

Keywords: Massage, blood pressure, glucose level, body fat percentage

\section{INTRODUCTION}

One of Indonesia's health development missions is to improve the degree of public health through various activities. Improved health status can be achieved by improving the nutritional status of the community, including the adult female group. Most of Indonesia's population is female and according to the results of the study as many as $32.9 \%$ of adult Indonesian women are obese while in West Sumatra approximately $30 \%$ of adult women are also obese (Riskesdas 2013). The high rate of obesity in adult women is increasing, especially in big cities. Nationally, the results of Basic Health Research showed that the 2007 obesity rate in adult women was $13.9 \%$, in 2010 it was $15.5 \%$ and in 2013 there was an increase to $32.9 \%$ (Riskesdas 2013). Incidence of obesity can affect the emergence of various degenerative diseases such as high blood pressure, diabetes mellitus, stroke, coronary heart disease and other degenerative diseases. Almost all degenerative diseases are the 10 highest causes of death in the world (WHO, 2018). The emergence of various degenerative diseases decreases productivity and life expectancy of a person.
Obesity can be caused by excessive food intake of fat sources. As a result of the accumulation of fat due to irregular eating patterns will cause obesity which results in narrowing of blood vessels and other effects. Food intake of fat and carbohydrate sources without being accompanied by physical activity for a long time, resulting in an imbalance between energy intake that exceeds the energy used. The excess energy will be converted into fat and buried in fat cells under the skin. In addition to excess food intake and lack of physical activity, obesity can also be caused by genetic disorders, metabolic disorders and technological advances that minimize motion.

There are several treatments that can reduce the incidence of obesity in adult women. Regulating food intake through dietary fats and carbohydrates is a treatment that is mostly done. Increasing physical activity with moderate intensity is another way that can reduce obesity or overweight in women. Other treatments that can be done to minimize obesity are through surgery or liposuction. Various ways of treatment to minimize the incidence of obesity or obesity that has been done a lot have weaknesses, among others, require uncomfortable 
efforts such as reducing food through diet and regular exercise with a strict exercise program. The disadvantages of high-risk obesity reduction methods such as surgery or liposuction can cause death and other risks. Based on the deficiencies in the treatment of obesity, a relatively safe and comfortable alternative is needed to reduce the risk of obesity. According to Darni (2009) massage can reduce obesity through decreasing the percentage of body fat by manipulation of movements performed on massage. In addition to reducing body fat percentage, massase can improve blood circulation and improve the cardiovascular system. Not many studies have proven the effect of exercise massage on the improvement of the cardiovascular system and body composition. Therefore research is needed to prove the effect of exercise massage on blood pressure and body fat percentage. This research contributes to the prevention of degenerative diseases such as high blood pressure, diabetes mellitus, stroke and coronary heart disease.

\section{METHODS}

This research uses quantitative methods with pre-experimental designs with one group pretest - post test design. In this study there is a preliminary test before being given treatment and also a final test after treatment, thus the results of the treatment can be known to be more accurate because it can compare with the situation before being given treatment (Sugiyono, 2015: 74). This research was conducted to see the effect of masaseth on blood pressure and body fat percentage of members of Dharmawanita Sport Science Faculty (FIK) This study only used one sample group without using a control group. The sample group is given a pre-test and then given treatment then post-test.

Data collection procedures in this study were divided into three waves, namely pretest, treatment and posttest. The procedures for implementing the pretest and posttest are the same. Initial tests by measuring blood pressure using a digital tensimeter and measuring the percentage of fat with a fat analyzer before being treated masase on research subjects. Then the study subjects were given a massage treatment on the back, neck and shoulders, and upper and lower extremities for 45 minutes with each movement done 6 times repetition, and carried out three times over 2 weeks. After the treatment period is completed, the final measurement / test is carried out.

The population in this study were 87 member of Dharmawanita FIK UNP mothers. The sample is part of the population of 10 people taken purposively. The sample criteria are BMI> $25 \mathrm{~kg} / \mathrm{m} 2$, blood pressure above $130 \mathrm{mmHg}$, willing to follow the study until it is finished and can control food, and not in sick condition.

To analyze the effect of massage on blood pressure and body fat percentage will be analyzed using $t$ test. Data obtained from the measurement results were analyzed using t-test (different) paired (pired t-test) with a significance level of $5 \%$. T-test yields $t$ value and probability value (p) which can be used to prove the hypothesis of the presence or absence of significant influence with a significance level of $5 \%$. How to determine whether or not significant is if the value ( $\mathrm{p}$ $<0.05)$ then there is a significant difference, if ( $p>0.05$ ) then there is no significant difference.

\section{RESULT AND DISCUSSION}

In the first stage the researchers measured the height and weight data of the sample and the age of each sample.

Table 1. Data Characteristics of Subject Data

\begin{tabular}{|c|c|c|c|c|}
\hline No & Subject & Height $(\mathrm{cm})$ & Weight $(\mathrm{kg})$ & Age (year) \\
\hline 1 & A & 155 & 68,9 & 49 \\
\hline 2 & B & 152 & 66,6 & 54 \\
\hline 3 & C & 160 & 72,2 & 54 \\
\hline 4 & D & 154 & 67,3 & 54 \\
\hline 5 & E & 150 & 73 & 61 \\
\hline 6 & F & 155 & 71,3 & 59 \\
\hline 7 & G & 158 & 83,9 & 49 \\
\hline 8 & H & 163 & 73,6 & 56 \\
\hline 9 & I & 162 & 70,7 & 49 \\
\hline \multicolumn{7}{|r}{} & 156,6 & 71,9 & 54,3 \\
\hline
\end{tabular}

From table 1. the data is obtained that the average height of the darma women of FIK UNP women is $156.6 \mathrm{~cm}$, the average body weight of members of Dharmawanita Sport Science Faculty (FIK) is $71.9 \mathrm{~kg}$, the average age of members of Dharmawanita Sport Science Faculty (FIK) UNP is 54.3 years. Based on the height and weight of the sample, the BMI value and the nutritional status classification of the sample are known as follows.

Table 2. Frequency Distribution of IMT Scores

\begin{tabular}{|c|c|c|c|c|}
\hline $\mathrm{NO}$ & IMT SCORES & CLASIFICATION & $F$ & $\mathrm{Fr}$ \\
\hline 1 & BMI < 17 & Very Thin & 0 & 0 \\
\hline 2 & BMI $17.0-18.5$ & Thin & 0 & 0 \\
\hline 3 & BMI 18.5 - 24.9 & Normal & 0 & 0 \\
\hline 4 & BMI 25.0 - 29.9 & Fat & 0 & 0 \\
\hline 5 & BMI $\geq 30$ & Obesity & 9 & $100 \%$ \\
\hline & 9 & $100 \%$ \\
\hline
\end{tabular}

From table 2, it is obtained that 9 people $(100 \%)$ of members of Dharmawanita Sport Science Faculty (FIK) UNP were classified as Obesity BMI (BMI $\geq 30$ ). Then the initial test is done by measuring blood pressure using a digital tensimeter and measuring the percentage of fat with a fat analyzer before being given a massage treatment to research subjects, the following data are obtained: 
Table 3. Pretest Data on Health Check Results of Dharmawanita Members FIK UNP

\begin{tabular}{|c|c|c|c|c|c|c|c|c|}
\hline No & Subject & $\begin{array}{c}\text { Blood } \\
\text { Pressure }\end{array}$ & Pulse & Height & Weight & Fat & KLS & GLS \\
\hline 1 & A & $113 / 59$ & 67 & 155 & 68,9 & 42,4 & 187 & 101 \\
\hline 2 & $\mathrm{~B}$ & $123 / 85$ & 87 & 152 & 66,6 & 40,9 & 279 & 109 \\
\hline 3 & $\mathrm{C}$ & $130 / 64$ & 76 & 160 & 72,2 & 41,6 & 298 & 109 \\
\hline 4 & $\mathrm{D}$ & $127 / 64$ & 75 & 154 & 67,3 & 43 & 294 & 146 \\
\hline 5 & $\mathrm{E}$ & $114 / 66$ & 54 & 150 & 73 & 51,2 & 220 & 146 \\
\hline 6 & $\mathrm{~F}$ & $136 / 74$ & 86 & 155 & 71,3 & 44,7 & 275 & 134 \\
\hline 7 & $\mathrm{G}$ & $103 / 64$ & 73 & 158 & 83,9 & 50,6 & 273 & 143 \\
\hline 8 & $\mathrm{H}$ & $134 / 81$ & 86 & 163 & 73,6 & 40,5 & 201 & 123 \\
\hline 9 & $\mathrm{I}$ & $115 / 78$ & 72 & 162 & 70,7 & 40,7 & 199 & 110 \\
\hline \multicolumn{2}{|l}{ RATA-RAJTA } & $122 / 70$ & 75,1 & 156,6 & 71,9 & 44,0 & 247,3 & 124,6 \\
\hline
\end{tabular}

\begin{tabular}{|c|c|c|c|}
\hline Water & Bone & Muscle & Calories \\
\hline 43 & 10,1 & 30,2 & 1822 \\
\hline 42,2 & 9,1 & 29,2 & 1717 \\
\hline 41,3 & 9,4 & 28,3 & 1853 \\
\hline 39,2 & 9,2 & 27,2 & 1776 \\
\hline 33,5 & 8,2 & 23,3 & 1817 \\
\hline 38,1 & 8,8 & 26,3 & 2039 \\
\hline 34 & 9,6 & 24 & 1919 \\
\hline 41,4 & 10,2 & 29,1 & 1882 \\
\hline 40,8 & 10,3 & 28,6 & 1848,6 \\
\hline 39,3 & 9,4 & 27,4 & \\
\hline
\end{tabular}

From table 3. data is obtained that the average blood pressure of members of Dharmawanita Sport Science Faculty (FIK) is $122 / 70$, the average fat of members of Dharmawanita Sport Science Faculty (FIK) is 44 , the average cholesterol of members of Dharmawanita Sport Science Faculty (FIK) is 247.3, the average glucose of Dharmawanita of FIK UNP was 124.6, the average calories consumed by members of Dharmawanita Sport Science Faculty (FIK) was 1848.6. After the treatment, the results of the posttest check on the health of members of Dharmawanita Sport Science Faculty (FIK) UNP were as follows. Then the study subjects were given a massage treatment on the back, neck and shoulders, and upper and lower extremities for 45 minutes with each movement done 6 times repetition, and carried out three times over 2 weeks. After the treatment period is completed, the final measurement / test is carried out. And posttest data obtained as follows:
Table 4. Posttest Data Health Check Results of Dharmawanita Members of FIK UNP

\begin{tabular}{|c|c|c|c|c|c|c|}
\hline No & PASIEN & TENSI & NADI & TB & $\mathrm{BB}$ & LEMAK \\
\hline 1 & $\mathrm{~A}$ & $115 / 67$ & 65 & 155 & 65,7 & 37,6 \\
\hline 2 & B & $121 / 71$ & 70 & 152 & 63,3 & 38,6 \\
\hline 3 & $\mathrm{C}$ & $110 / 53$ & 65 & 154 & 66,2 & 41,3 \\
\hline 4 & D & $120 / 67$ & 62 & 160 & 70,8 & 40,8 \\
\hline 5 & $\mathrm{E}$ & $114 / 71$ & 62 & 150 & 72 & 49,9 \\
\hline 6 & $\mathrm{~F}$ & $121 / 68$ & 70 & 155 & 69,3 & 42,6 \\
\hline 7 & $\mathrm{G}$ & $121 / 73$ & 69 & 158 & 81,3 & 50 \\
\hline 8 & $\mathrm{H}$ & $119 / 68$ & 70 & 163 & 71 & 38,1 \\
\hline 9 & I & $118 / 70$ & 71 & 162 & 69,4 & 40 \\
\hline \multicolumn{2}{|c|}{ RATA-RATA } & $118 / 68$ & 67,1 & 156,6 & 69,9 & 42,1 \\
\hline
\end{tabular}

\begin{tabular}{|c|c|c|c|c|c|}
\hline KLS & GLS & AIR & TULANG & OTOT & KALORI \\
\hline 154 & 98 & 40,1 & 10,1 & 28,2 & 1740 \\
\hline 200 & 91 & 38,4 & 9,1 & 26,4 & 1725 \\
\hline 211 & 106 & 39,3 & 9,2 & 27,3 & 1791 \\
\hline 189 & 79 & 39,5 & 9,3 & 27,5 & 1860 \\
\hline 198 & 98 & 31,4 & 8,2 & 22,7 & 1813 \\
\hline 201 & 104 & 39,3 & 8,9 & 27,2 & 1786 \\
\hline 201 & 99 & 34 & 9,6 & 24 & 2000 \\
\hline 177 & 96 & 40,5 & 9,4 & 28,4 & 1866 \\
\hline 188 & 96 & 40,1 & 10,4 & 28,8 & 1874 \\
\hline 191 & 96,3 & 38,1 & 9,4 & 26,7 & 1828,3 \\
\hline
\end{tabular}

From table 4 . the data is obtained that the average blood pressure of darma women of FIK UNP is $118 / 68$, the average fat of members of Dharmawanita Sport 
Science Faculty (FIK) is 42.1, the average cholesterol of members of Dharmawanita Sport Science Faculty (FIK) is 191, the average glucose of members of Dharmawanita Sport Science Faculty (FIK) is 96.3, the average calories consumed by members of Dharmawanita Sport Science Faculty (FIK) is 1828.3.

\section{CONCLUSION}

From the results of the research that has been carried out obtained data that there was a decrease in levels of fat, cholesterol, glucose, and blood pressure of the mother of members of Dharmawanita Sport Science Faculty (FIK), where the average initial fat test level was 44 , changed to 42 . The results also showed that the average cholesterol in the initial sample test 247.3, it dropped to 191. The average initial test sample Glucose 124.6, dropped to 96.3. And the average initial blood pressure test sample of $122 / 70$ drops to $118 / 68$.

\section{REFERENCES}

[1] Kemenkes RI. 2013. Riset Kesehatan Dasar. Badan Penelitian dan Pengembangan Kesehatan. Kementerian Kesehatan RI.

[2] WHO. 2018. TOP 10 Causes of Death. https://www.who.int/news-room/fact- sheets/detail/the-top-10-causes-of-death. Diakses tanggal 20 Februari 2019.

[3] Darni. 2009. Masase Olahraga Dasar Teori dan Manipulasi. Wineka Media

[4] Priyonoadi, B. 2011. Sport Massage. Yogyakarta: Fakultas Ilmu Keolahragaan Universitas Negeri Yogyakarta.

[5] Magfirah, I. 2016. Hubungan Kualitas Tidur Dengan Tekanan Darah Pada Mahasiswi Program Studi S1 Fisioterapi Angkatan 2013 Dan 2014 Di Universitas Hasanuddin. Skripsi. FK: Universitas Hasanudin Makasar.

[6] Amirudin, M.A, dkk. 2015. Analisa Hasil Pengukuran Tekanan Darah Antara Posisi Duduk dan Posisi Berdiri pada Mahasiswa Semester VII (Tujuh) Ta. 2014/2015 Fakultas Kedokteran Universitas Sam Ratulangi. Jurnal eBiomedik (eBm),Volume3, Nomor 1.Hlm. 125-129.

[7] Anggara, F.H.D dan Prayitno, N. 2013. FaktorFaktor yang Berhubungan dengan Tekanan Darah di Puskesmas Telaga Murni, Cikarang Barat Tahun 2012. Jurnal Ilmiah Kesehatan, 5(1). Hlm. 0-25.

[8] Wiarto, G. 2013. Fisiologi dan Olahraga. Yogyakarta: Graha Ilmu.

[9] Andriani dan Bambang Wirjadmadi. 2012. Pengantar gizi masyarakat. Jakarta:PT. Fajar Interpratama Mandiri. 